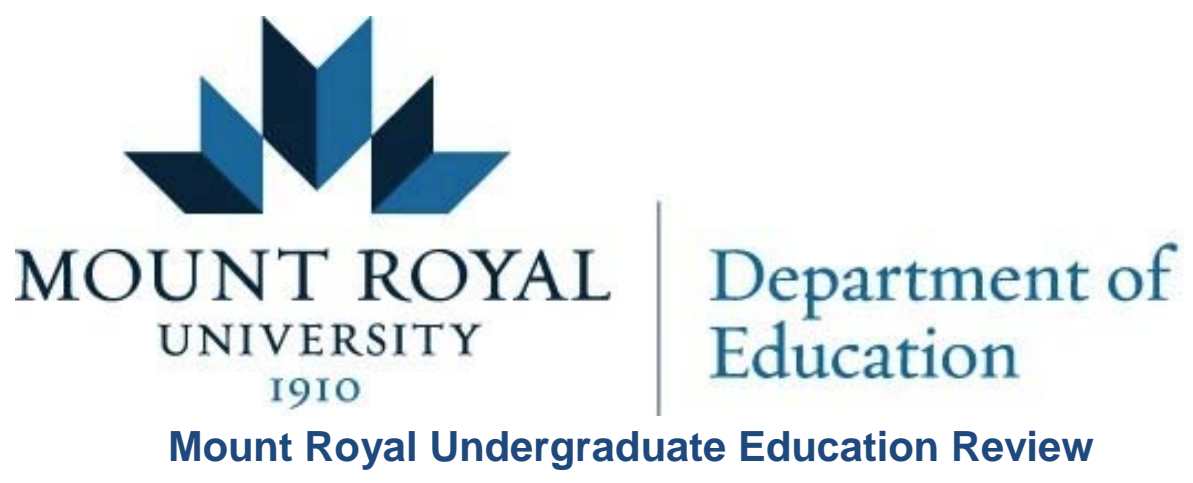

Volume 1(3)

Fall 2015

\title{
Math learning disabilities and digital technology
}

Sihan Lin, Mount Royal University

\section{Link to Digital Story}

\begin{abstract}
This research study addressed the question that how could the educational technologies help students in learning mathematical concepts in elementary, and especially focused on students who have math learning disabilities. After gathering background information from several scholarly articles, I conducted an online survey and sent out to my education class as well as my friends. For further information, I interviewed my university math professor, and my current mentor teacher in person. There were a total of 15 participants attending my research projects which including 13 online survey participants, and two interviews. According to my investigation, the result showed that more than half of my survey participants never heard about math learning disabilities, and about half of them had used digital technologies in learning math concepts. This research project is important to my own learning as a teacher candidate because it reminded me the challenges of using digital technologies, and also provided me some strategies when teaching math with technologies in an elementary class.
\end{abstract}




\section{Introduction}

Last year, I was able to observe a grade 4 class at Calgary Girls' School as a student teacher and to visit Dr. Oakley School. Such experiences totally changed my view about how technology influence students' learning and their understanding. Calgary Girls' School is an inquiry-based learning school, and each student has their own ipad. When I went to Dr. Oakley School and learned about Universal Design for Learning, I realized the importance of student needs.

According to my observations and my own teaching experiences, I found it was hard to integrate technology into math teaching. I taught 7 times table in my class, and used one online presentation software to present the information more attractively. Especially for lower grades, they struggled with addition and subtraction, and I had noticed that most of them were either just memorizing or using finger to count it. Therefore, I would like to know how could the educational technologies to be used when teaching math and help them to understand math concepts.

One girl in my field experience class last semester had trouble with math, and told me that she got the math phobia when she was struggling with a math problem one day. It makes me remember my research paper Incorporating Gameplay into Curriculum in Assisting Elementary Students Achieve a Better Learning in Mathematics that I did for my English course last year about how could the digital game-based learning help students in learning mathematics. According to my research, if the teachers can properly use digital game-based learning in the class, it could change students attitudes towards mathematics. Not only the digital game-based learning, how could other educational technologies help learners to build the positive learning attitudes? How can digital technology be used to help the elementary level students who have difficulty in learning mathematics? What are the challenges when incorporating digital technologies into an elementary class? What are some suggestions and strategies I could use in my future math teaching?

\section{Background}

The official definition of learning disabilities from the Learning Disabilities Association of Canada (LDAC) (2002) is that "Learning Disabilities refer to a number of disorders which may affect the acquisition, organization, retention, understanding or use of verbal or nonverbal 
information” (para. 1). Also, they list two examples that can be considering as mathematics learning disabilities which are computation and problem solving (LDAC, 2002, para. 3).

Then, I researched on the topic about digital technologies and mathematics in elementary. Many researchers had completed projects about how can different digital technologies help elementary level students to learn math concepts. Some of their researches only focused on students who have math learning disabilities which is my research topic, and some of the articles just discussed general math learning.

Burns, Kanive and DeGrande (2012) studied 226 grade three and four students who have difficulty in learning math and used the computer-based math fluency (CBMF) intervention to improve their math skills. According to the results, they concluded that CBMF was effective for helping those students to achieve better academic performance.

Kiger, Herro and Prunty (2012) researched the influence of using Mobile Learning Intervention (MLI) in math learning. They provided iPod devices for each participant, and totally 87 grade three students were involved in this experimental study. After using math apps to practice multiplication 10 minutes every day, the result showed that the average grade of postintervention multiplication test was higher than the pre-test.

Nicoleta (2011) discussed about how the eLearning models can help elementary level students to learn math in Germany. The authors researched 158 pupils in Germany, and they compared the students' grades before and after using electronic models in math teaching. The result showed that electronic models learning was able to enhance students' math performance for each grade they studied especially for grade four kids.

Salaschek and Souvignier's study (2014) focused on how web-based mathematics progress monitoring can affect students’ math skills specifically for number sense and computation. They investigated 414 grade two students in Germany, and tested their knowledge level every three weeks. At the end of the study, they found that students' test scores were significantly increased after using progress monitoring.

Ysseldyke and Bolt (2007) researched progress monitoring system in both elementary and middle school. They set up two groups which the experimental group integrated continuous progress monitoring and instructional management system into their math curriculum, and the control group remained the regular math curriculum. When comparing pre- and post-test scores, 
they concluded that the progress monitoring system was useful for students to improve their math outcomes.

Those five articles help me to build a solid background knowledge about how can digital technologies facilitate students’ math learning, and get familiar with various math related digital technologies.

\section{Research Context}

I conducted my research study at Mount Royal University; then, I gathered the majority of my data from Mount Royal University, and my school placement which is Altadore School. The primary participants in my research study were professors and education students at Mount Royal University, and my mentor teacher in my field experience class. There were totally 15 participants involved in my research, which were 13 survey participants, and 2 interviews. Before I starting my research, I had completed the Government of Canada Ethics Certificate for my research, and attached my certificate as shown below(Figure 1). All the responses and data I gathered will be confidential and completely anonymous. Additionally, I had ensured that all the participants are above 18.

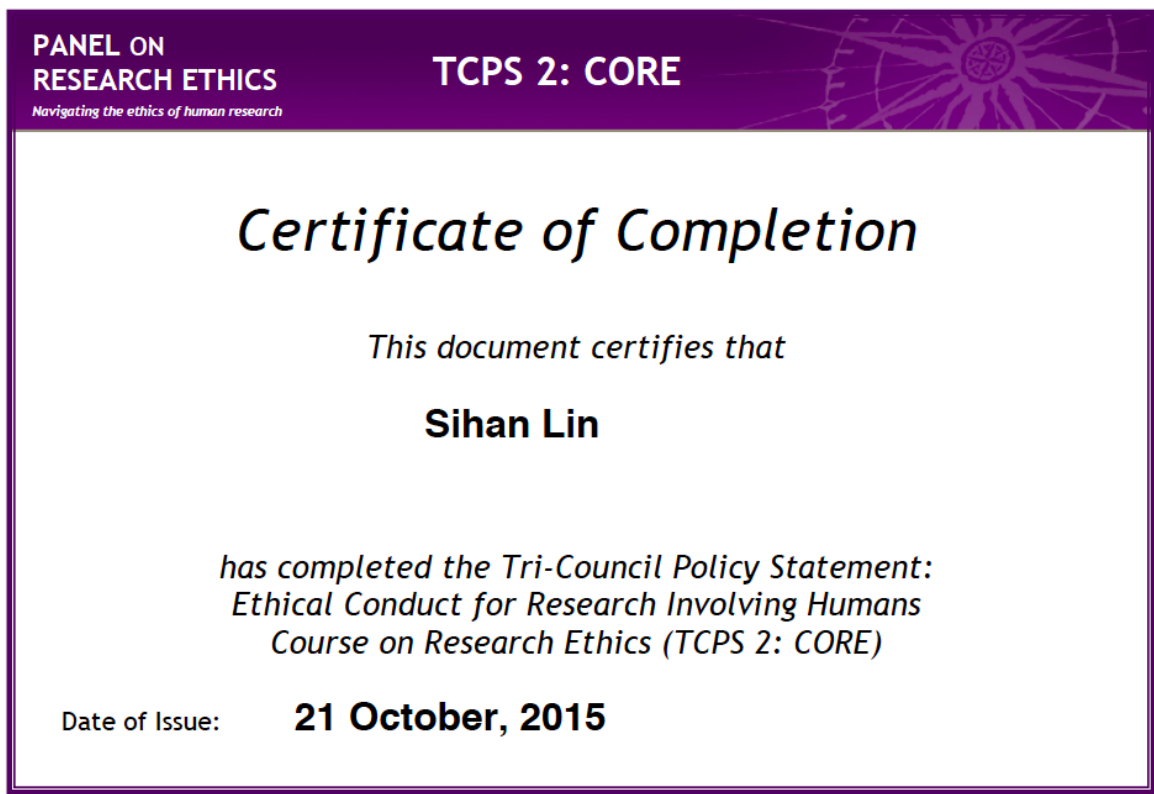

Figure 1. The Government of Canada Ethics Certificate

\section{Methods of Investigation}

The general approach of this action research was a correlational quantitative study that I only looked for association between math learning and digital technologies. The specific 
methods of data collection I used were the online survey, interviews, observations, and my field notes. First, I conducted an online survey by using the Google Form(Figure 2), and sent to other education students in my EDUC 2325 class via email. The online survey helped me to get the overall idea about my participants' personal experiences and opinions about math learning and digital technologies. Besides that, I would like to know the professional perspectives on this topic, so I conducted two face-to-face interviews with my mentor teacher at my field experience school, and one of my Mathematics professor at Mount Royal University. I got permission from the participants, and used my phone to record the interviews.

To analyze data I collected for the online survey, I used Google Spreadsheet, and converted all multiple choice questions to graphs. To analyze responses for the short-answer question, I converted all the responses to a word cloud by using the WordClouds.

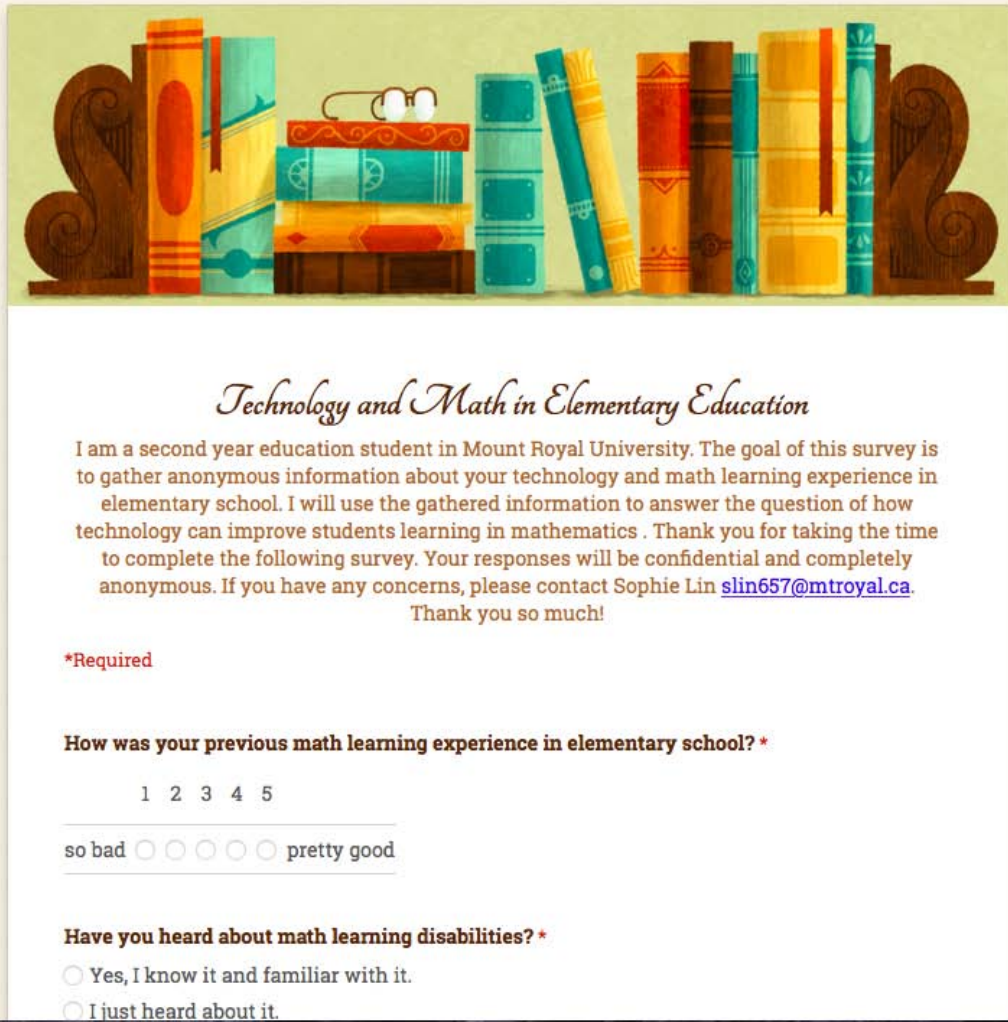

Figure 2: Online Survey

\section{Findings}

For my online survey, I created 5 questions about participants’ technology and math learning experience in elementary school, and totally got 13 responses back which 11 from my education class peers and 2 responses from my friends in university. Also, I interviewed my 
mentor teacher at Altadore School, and one of my math professors at Mount Royal University.

How was your previous math learning experience in elementary school? (13 responses)

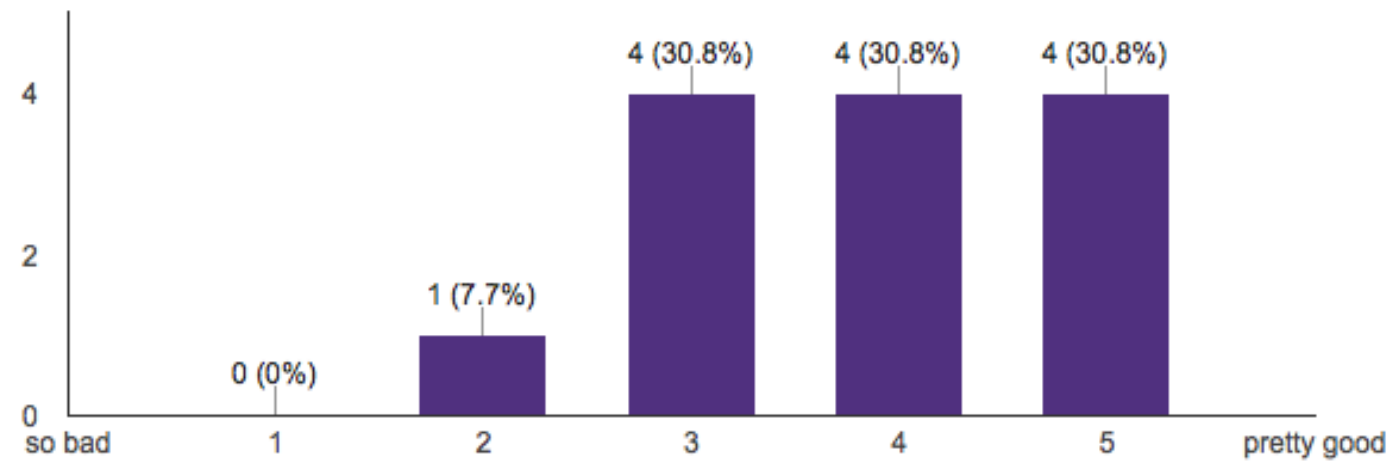

Figure 3: Participants Math Learning Experience in Elementary

For the first question, I asked the participants about their previous math learning experience when they were in elementary school. The participants should choose a score from one to five depending on their math learning attitudes in elementary. According to Figure 1, it showed that only one participants had negative math learning experience. However, since all of my participants are university students, I should be aware of that all the responses I gathered were from people have attended higher level of education.

\section{Have you heard about math learning disabilities? (13 responses)}

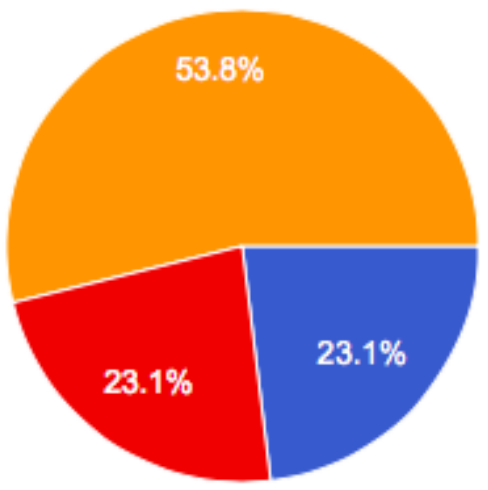

Yes, I know it and familiar with it.

I just heard about it.

No, I don't know it.

Figure 4: Participants Previous Knowledge about Math Learning Disability 
For the second question, I wanted to know my participants background knowledge about math learning disabilities. I was surprised that more than half of my participants do not what it is, because eleven of my survey participants are education students from my EDUC 2325 course. However, learning disabilities become a serious problem nowadays, and as a teacher candidate, I should notice the diversity in education.

\section{Have you ever used technology when learning math concepts? (13 responses)}

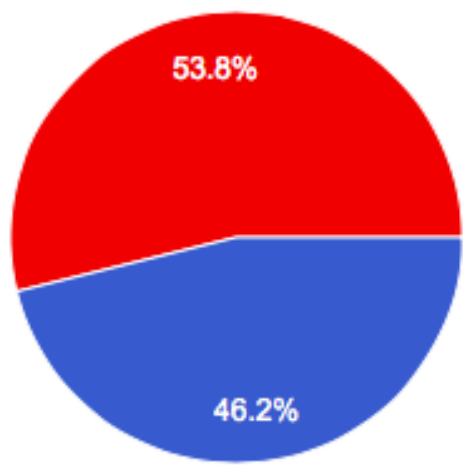

No, I never use it.

Yes, I have used educational technology.

Figure 5: Participants Elementary Learning Experiences of Using Technology to Facilitate Math Concepts Understanding

Based on the first question, I wanted to know whether they have used technology to help with math learning in elementary. The proportion is about half and half. This result informed me that my participants previous learning experience of math and technologies. I was surprised that about half of them never use technologies to facilitate their learning on math. However, I should keep in mind that back to ten years ago, digital technologies were not widely used in the elementary classroom. Nowadays, digital devices like the SMART Board and the projector are in common use in elementary education. 


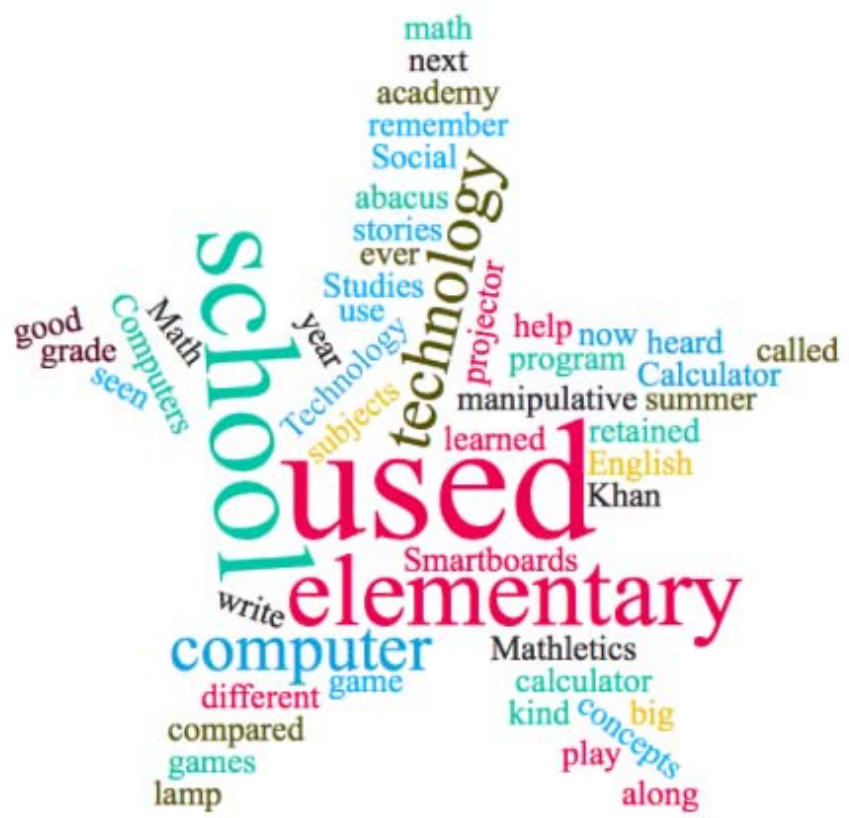

Figure 6: Word Cloud of All Responses From the Survey Short-answer Question "What kind of technology you have used in elementary school?”

From the Word Cloud, my participants provided various digital technologies they have used before such as computers, calculator, Mathletics, Khan Academy and abacus. The figure 6 gave me an overall ideas of what types of technologies my participants used. Then, for the next question, I would like to know their frequency of using those technologies.

\section{How often did you use this technology? (13 responses)}

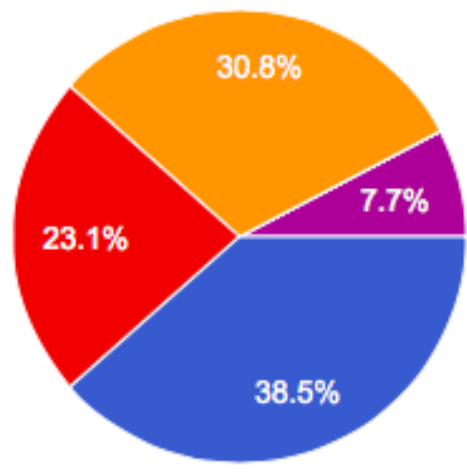

Every day

Once or twice a week.

Once or twice a month.

Once or twice a semester.

Once or twice a year.

Figure 7: Frequency of Using Digital Technology to Learn Math Concepts

From the figure 7, I was surprised to see that more than one third of my participants used educational devices every day. There is no doubt that practice makes perfect; however, it made 
me to consider the idea of reliance. Digital technologies have both sides: it can promote better understanding, but students might become too depend on it. Especially for elementary kids, they are sensitive and vulnerable, so that educators should notice how to create a respectful and safe online learning environment for them.

Table 1.

Interview Questions and Responses

\begin{tabular}{|c|c|}
\hline Interview questions & Participants’ responses \\
\hline $\begin{array}{l}\text { Have you used technologies } \\
\text { when teaching math? }\end{array}$ & $\begin{array}{l}\text { Participant 1: "I used the PowerPoint for presentation sometimes, and } \\
\text { depends on the math class, I have used the Excel for doing simple math } \\
\text { graphs and doing calculation on the classroom that students can see. I } \\
\text { have doc applies of the webs then they show visual things like rotating } \\
\text { surface that you can see the whole thing. And there are different } \\
\text { applies for different things in mathematically on the web.” } \\
\text { Participant 2: "I used Xtramath in class, and helped them to practice } \\
\text { simple addition." }\end{array}$ \\
\hline How efficient it is? & $\begin{array}{l}\text { Participant 1:“ I think for some of them it helps them for the } \\
\text { visualization on certain things. It helps them when they can actually } \\
\text { see and made it certainly.” } \\
\text { Participant 2: “They are still learning. Even logging in right now as } \\
\text { you saw is a problem, so we need to get better on that. It will be better } \\
\text { if you have computers at classroom all the times, but we have to book } \\
\text { them and they have to drag the cart and we have to get them to set up } \\
\text { and help them on charge.” }\end{array}$ \\
\hline $\begin{array}{l}\text { What do you think math } \\
\text { learning disability is? }\end{array}$ & $\begin{array}{l}\text { Participant 1: "I do think different people have different strengthens, } \\
\text { and for some people, it is not just simple as strengthless and weakness, } \\
\text { but there is something that sometimes is correctable that will let you }\end{array}$ \\
\hline
\end{tabular}




\begin{tabular}{|l|l|}
\hline & $\begin{array}{l}\text { overcome it." } \\
\text { "When you have some trouble with math, and makes you } \\
\text { think it harder for you or any other field. When you have trouble with } \\
\text { something, it can like it less or you do not want to engage it." }\end{array}$ \\
\hline $\begin{array}{l}\text { Have you knew anyone who } \\
\text { has math learning } \\
\text { disabilities? }\end{array}$ & $\begin{array}{l}\text { Participant 1: "I do see people who don't like math but they can do it } \\
\text { and will do if they have to, but I see people who try every hard and } \\
\text { they never get it." }\end{array}$ \\
$\begin{array}{l}\text { Participant 2: "Well, I did not like math and a such person when I was } \\
\text { in elementary, but when I became a teacher, I should teach my students } \\
\text { and it becomes better." }\end{array}$ \\
\hline $\begin{array}{l}\text { For the elementary class, } \\
\text { what do you think how can } \\
\text { technologies help students } \\
\text { who have math learning } \\
\text { disabilities? }\end{array}$ & $\begin{array}{l}\text { Participant 1: "I think it has potential to help but I am also afraid that } \\
\text { will be a crash and they will become too dependent on it. Sometimes } \\
\text { you become too dependent on the technology and can't function } \\
\text { without it, and sometimes it takes away your ability to think because } \\
\text { you just thinking term of what button do I press for it instead of what } \\
\text { am I doing overall. You have to be careful when you using technology. } \\
\text { It does have the potential I mean I can really see for visualization for } \\
\text { example, but if you become too depend on it, it is easy to become lazy } \\
\text { and not trying to learn things.” }\end{array}$ \\
\hline
\end{tabular}

From the two interviews and my survey data, I had collected information I need from my participants, and understood their ideas towards digital technologies. I learnt a lot from the interviews about some challenges and suggestions when using technologies in elementary class. Especially for students who have math learning disabilities, it is true that they need specially helps, but educators should help them to improve some basic skills like how to $\log$ in/log off, and how to use such devices at first. Otherwise, the digital technology will become a new learning barrier for them. 


\section{Conclusions and Recommendations}

In my own research, I have involved various digital technologies such as the Google Form and the Google Spreadsheet, and it is important for me as a learner. My own research provided me an outline about my participants' previous math learning experiences, and some digital technologies they have used. According to my interviews, I noticed that digital technologies is heavily used in school nowadays, and some suggestions I got from my participants helped me to better understand students' needs. For my future teaching, I should care about how to guide my students to use technology properly, and be aware of their competencies. Also, I should inspire my students' mathematical skills with the assistance of digital technologies, but they should not depend on that too much.

The research project in this semester encouraged me to continue my study about students' math learning attitudes, and math learning disabilities. I would like to improve my research by adding more survey questions, and to get in-depth responses about their attitudes towards math learning disabilities. I would like to know more about how efficient those digital technologies are, and how to incorporate into elementary math class appropriately. I believe that this research study just a beginning of my learning, and I will continue studying on this topic.

\section{References}

Burns, M. K., Kanive, R., \& DeGrande, M. (2012). Effect of a computer-delivered math fact intervention as a supplemental intervention for math in third and fourth grades. Remedial and Special Education, 33(3), 184-191. http://dx.doi.org/10.1177/0741932510381652

Kiger, D., Herro, D., \& Prunty, D. (2012). Examining the influence of a mobile learning intervention on third grade math achievement. Journal of Research on Technology in Education, 45(1), 61-82.

Learning Disabilities Association of Canada. (2002). Official definition of learning disabilities. Retrieved December 8, 2015, from http://www.ldac-acta.ca/learn-more/ld-defined

Nicoleta, S. (2011). How can technology improve math learning process. Procedia - Social and Behavioral Sciences, 11, 170-174. http://dx.doi.org/10.1016/j.sbspro.2011.01.055

Salaschek, M., \& Souvignier, E. (2014). Web-based mathematics progress monitoring in second grade. Journal of Psychoeducational Assessment, 32(8), 710-724. http://dx.doi.org/10.1177/0734282914535719

Ysseldyke, J., \& Bolt, D. M. (2007). Effect of technology-enhanced continuous progress 
monitoring on math achievement. School Psychology Review, 36(3), 453-467. 